\title{
Reading assignments in geography instruction: a (non-)functional part of a teacher's approach
}

\author{
Michala Kafková*, Dana Řezníčková
}

Charles University, Faculty of Science, Department of Social Geography and Regional Development, Czechia

* Corresponding author: michala.kafkova@seznam.cz

\begin{abstract}
This article presents results of the research focused on reading assignments in geography teaching. The approaches of Czech geography teachers to reading assignments are explored by using the method of grounded theory. Altogether 22 teachers from secondary school participated in the research. The typology of teacher approaches and the identification of factors that influence the teacher's inclusion of reading assignments in the disciplines was developed. The teachers' attitudes show that their preferences in the general notion of (not only) geography are reflected, and that the constructs of their beliefs or personal theory play an important role. These factors can take on both supportive and limiting forms, depending on the context that is shown in the article with the aid of a paradigmatic model. The results are situated in relation to the teacher's professional learning.
\end{abstract}

\section{KEYWORDS}

reading assignments; geography; professional knowledge; vision and action; teacher's beliefs; grounded theory; secondary school; Czechia

Received: 6 September 2019

Accepted: 27 July 2020

Published online: 4 November 2020

Kafková, M., Řezníčková, D. (2020): Reading assignments in geography instruction: a (non-)functional part of a teacher's approach. AUC Geographica 55(2), 218-228

https://doi.org/10.14712/23361980.2020.16

(C) 2020 The Authors. This is an open-access article distributed under the terms of the Creative Commons Attribution License (http://creativecommons.org/licenses/by/4.0). 


\section{Reading in geography: a typology of teacher's approach}

The topic of reading literacy of students is frequently discussed in the academic community. Our article focuses on reading in the disciplines or on the reading of students in subjects beyond the Czech language. We examine how teachers approach the inclusion of reading in the teaching of geography and which factors influence their approach.

Czech academic literature lacks a developed discussion of reading in the disciplines. Czech academic interest focuses primarily on pre-literacy and beginning literacy. Havlínová (2016) summarizes developments in these areas. Research examining the current state and development of literacy among students from the second level of elementary schools and secondary schools is less frequent. Radváková's (2015) article exploring secondary school student reading is one example.

In Anglo-Saxon countries (UK, USA, Australia, New Zealand) there are a number of papers that discuss the benefits of reading (and writing) in developing knowledge and skills in various school's subjects. This is due to the fact that the deliberate development of reading in the disciplines began to be supported as early as the 1920s (Shanahan, Shanahan 2012). Since about the early 1990s, there have been some changes in the concept and directions of research relating to reading in the disciplines (Shanahan 2013). The publication of Shanahan and Shanahan's (2008) article, in which they present a model of disciplinary literacy, can be viewed as a turning point. It is characterized by a shift from the simple using of general reading strategies (content area reading) towards the more content-specific readings that comprise disciplinary literacy. The authors argue that general reading strategies should be adapted to the various disciplines in such a way as to help students not only to read, but also to think, write, communicate and act in a way that reflects the specifics of the discipline. The aim of such teaching is not a state in which each student achieves the same level of reading, respectively disciplinary literacy in different subjects. Rather, the object is for students, regardless of their varied interests (some are more into geography, others history and others are musically inclined), to be able to read, write and think independently in various disciplinary situations.

The existence of this ongoing academic debate in Anglo-Saxon countries about why and how to utilize reading in subjects does not mean that there is not room for improvement in school practices. Many teachers use reading in the disciplines only on rare occasions, taking a skeptical stance to the method (e.g. Moje 2008). Nonetheless, the existence of various curricular documents (e.g. Common Core State Standards 2010; Next Generation Science Standards 2013; Common Core English Language Arts and Geography
Connection 2013; The New Zealand Curriculum 2009) that systematically detail requirements for reading in the disciplines has a significant impact on the implementation of reading in subject areas. This is partly because teachers have standards with a obligatory or recommended nature. This emphasis is also reflected in changes in teacher education (Gilles et al. 2013). A consistent theme throughout the cited sources focused on how teachers could develop or are developing the literacy of their students, because reading and writing as well - is a natural part of the discipline in question. The question "why" read in various subjects no longer receives the emphasis; it is more about "how" to read in the subjects.

If students are to meet and learn from a variety of texts in the school's subjects, then they need appropriate support or guidance from the teacher. We agree with Hattie (2012) that, while teaching students depends on many factors, the teacher - his or her beliefs and grasp of the responsibility for student learning along with corresponding actions - has the greatest instructional impact (Hattie 2012). We expect that students make the greatest progress as their teachers view themselves as those that adjust teaching by consistently observing their work through the results of teaching each of their students and seek improvement. Among other things, this requires knowledge of their own discipline and strategies or approaches for reaching desired outcomes with students. Directing research at teachers and exploring what they know or what they believe can be grounded in the conclusions of several authors (Korthagen 2011; Timperley 2011; Hattie 2012; Slavík et al. 2014 and others), who consider it fundamental to start professional development by uncovering what a teacher already knows, can do, thinks, and only then defining the focus of future professional learning.

We anchor a teacher's approach to reading in the disciplines with reference to the authors Minaříková and Janík (2012) in relation to three basic elements of teacher professionalism. Teacher's approach is primarily based on professional knowing. This includes a teacher's acquired knowledge, skills and beliefs concerning reading in the disciplines as well as other areas (knowledge of student, selection and fulfilment of selected goals, etc., see Griffith and Lacina (2017). Second, it is also influenced by the character of teacher's professional vision. We understand this as the ability to observe, carry out pedagogical reflection and interpret observations in their broader context. Third, a teacher's approach expresses itself in professional action, in the way that a teacher utilizes reading in geography instruction. We followed our research to at least partially explore teacher knowing and vision regarding reading in the disciplines. We consider a teacher's beliefs to be an important part of professional knowing, which may or may not be the engine of his action. To state it more precisely, we view a teacher's beliefs - in agreement with Hutner 
and Markman (2016) - as a so-called enabling mental structure that only impacts his or her actions if it is active in a given moment and context.

Teacher approaches to reading in the disciplines share similar characteristics with concepts such as subjective theories, personal theories, teacher's thoughts or instructional approaches. These concepts differ in several respects, but they all involve mental structures that the teacher formulates, they tend to be rather stable, and they significantly impact a teacher's ultimate actions. Grasping these concepts for the purposes of research is quite difficult, due to their nature as implicit, relatively unconscious and unbounded constructs (Janík 2005; Koubek 2015).

We did not find examples of academic research categorizing teacher approaches to geography Some methodological guidance were the studies Catling (2004) and Hanus, Havelková (2018). Catling's wor reflects the overall concept of geography. Catling expanded upon Walford's typology from 1996 adding to the initial question "What is geography?" a second question "Why teach geography?" Hanus and Havelková (2018) build upon the Catling's work by studying geography teachers' approaches for developing map skills in schools in Czechia. They identified three types of geography teachers (Navigators,
Problem-oriented and Source-oriented), characterized by certain map skills. Discussing their results, they point out the mutual relationship between preferred map skills and geographic skills, in other words, a teacher's general view of geography instruction.

\section{Research methodology}

The initial state of knowledge on the issue of reading in the disciplines, as described above, influenced the focus of our research, which seeks a deeper understanding of geography teacher approaches regarding the inclusion of reading in geography instruction. We have narrowed the scope of this otherwise broad issue with a central research question:

How do teachers approach the inclusion of reading into geography lessons?

The unresearched nature of the topic helped determine our methodological approach: qualitative research. The grounded theory method was chosen as a research design. We employed the framework designed by Strauss and Corbin (1999). Following the principles of qualitative research (e.g. Hendl 2005), in

Tab. 1 Basic characteristics of respondents.

\begin{tabular}{|c|c|c|c|c|}
\hline Teacher & Sex & Age & Type of school & Regions \\
\hline A & Woman & $40-49$ & Elementary school & South Bohemian Region \\
\hline C & Man & $30-39$ & Elementary school & South-Moravian region \\
\hline D & Man & $40-49$ & Extended length grammar school & Prague \\
\hline $\mathrm{E}$ & Man & $30-39$ & Extended length grammar school & Prague \\
\hline $\mathrm{F}$ & Man & $30-39$ & Extended length grammar school & Prague \\
\hline G & Man & $20-29$ & Extended length grammar school & Prague \\
\hline $\mathrm{H}$ & Woman & $30-39$ & Elementary school & Olomouc region \\
\hline $\mathrm{CH}$ & Woman & $30-39$ & Elementary school & Moravian-Silesian Region \\
\hline 1 & Woman & $30-39$ & Elementary school & Moravian-Silesian Region \\
\hline J & Woman & $30-39$ & Elementary school & Vysočina Region \\
\hline K & Man & $30-39$ & Extended length grammar school & Prague \\
\hline $\mathrm{L}$ & Man & $30-39$ & Extended length grammar school & Central Bohemian Region \\
\hline M & Man & $30-39$ & Extended length grammar school & South Bohemian Region \\
\hline $\mathrm{N}$ & Woman & $30-39$ & Elementary school & Vysočina Region \\
\hline $\mathrm{O}$ & Man & $30-39$ & Elementary school & Central Bohemian Region \\
\hline$P$ & Man & $30-39$ & Extended length grammar school & Prague \\
\hline $\mathrm{R}$ & Man & $30-39$ & Extended length grammar school & Prague \\
\hline S & Woman & $20-29$ & Extended length grammar school & Prague \\
\hline $\mathrm{T}$ & Man & $40-49$ & Elementary school & Moravian-Silesian Region \\
\hline V & Woman & $40-49$ & Extended length grammar school & Prague \\
\hline Y & Man & $20-29$ & Elementary school & South Bohemian Region \\
\hline Z & Woman & $30-39$ & Elementary school & Moravian-Silesian Region \\
\hline
\end{tabular}

Source: own research investigation 
the process of carrying out the research, we further specified our objectives with two related questions:

1) What types of approaches to disciplinary reading are obvious to geography teachers?

2) What causes the apparent similarities and differences among teacher approaches?

The research included 22 geography teachers, which were known to have some experience with incorporating reading into their instruction. Half of the respondents (i.e. 11) were from extended length (6 or 8 years) grammar schools, while the other portion represented elementary schools (for more information see Table 1). All were fully qualified geography teachers. Primarily, these were teachers with connections to the Reading \& Writing for Critical Thinking program or the project "We help schools succeed". We made no distinctions considering the types of experience teachers had with reading; for example, whether a teacher regularly included reading, the ways that students worked with texts, how their work was evaluated, etc. We employed this targeted selection because of the character of the central research question and in accordance with qualitative research methods (Švaříček and Šed'ová 2007). We considered it necessary to collect data from teachers who perform reading in geography, in order to obtain the widest possible repertoire of responses from teachers who themselves state that they have experience with reading.

Data collection was carried out initially from 2013 to 2015 and then again in 2017. Teachers answered, in writing, nine open questions that were divided into two surveys. We chose to use written responses in order to allow respondents time to think over the answers to conceptual questions. Table 2 show all questions. In this paper, we present the results of an analysis of the three questions used (in Table 2 they are highlighted in bold). This questions focus primarily on the concept of reading in geography instruction. The remaining concerned the preferred objectives of geographical education and the evaluating the complexity of texts use in geography lessons. These were analyzed in a separate research.

Data analysis was broken into three phases.

The first phase, open coding, involved word-forword exploration of teachers' answers followed by the classification of significant units (words, phrases, entire sentences) that were marked with terms. Over the course of the research, these terms were generalized into categories.

The second phase, axial coding, sought to define connections among the discovered categories, searching for correlations or possible causal relationships. For this phase, we used a paradigm model, which we tailored to our research and which can be seen in Figure 1. The paradigm model shows relationships a central phenomenon (i.e. the inclusion of reading in geography instruction) and other parts that we define, in accordance with Strauss and Corbin (1998), as detailed below. They are:

a) causal conditions, i.e. conditions or factors that led to the occurrence of a certain manifestation e.g. inspiration from colleagues;

b) intervening conditions, i.e. conditions or factors tied to a teacher's strategies for acting - e.g. time for reading;

c) context, i.e. conditions or factors describing the circumstances in which a manifestation occurs e.g. to what level does the entire school, or colleagues from the teaching staff, support literacy development;

d) strategies for action, i.e. a teacher's strategies for realizing reading in the disciplines leading toward a certain purpose for certain conditions and in a certain context - e.g. a teacher uses reading to awaken student interest about a research question or topic;

e) consequences of action, i.e. student activities related to reading in the disciplines that result from the actions of the teacher - e.g. students working with tables and graphs.

The categories were placed into the model such that their position would correspond as much as possible with their respective functions within the schema (e.g. inspiration from colleagues is a causal condition leading to a manifestation, i.e. the inclusion of reading into a geography class). The placement of viewpoints within the relationships was later confirmed with actual survey data and any necessary adjustments were made.

Tab. 2 Set of questions for teachers.

\begin{tabular}{|c|c|}
\hline $\begin{array}{l}\text { A set of questions focused } \\
\text { primarily on reading in the } \\
\text { discipline: }\end{array}$ & $\begin{array}{l}\text { A set of questions focused } \\
\text { primarily on the concept of the } \\
\text { goals of geographical education: }\end{array}$ \\
\hline $\begin{array}{l}\text { Why do you include reading } \\
\text { a geographical text in the } \\
\text { geography instruction? }\end{array}$ & $\begin{array}{l}\text { What are the goals in your } \\
\text { geography instruction? }\end{array}$ \\
\hline $\begin{array}{l}\text { When including a reading } \\
\text { - you proceed rather from } \\
\text { a specific text } \\
\text { - or are you looking for text for } \\
\text { a given topic and skills used? }\end{array}$ & $\begin{array}{l}\text { Do you perceive other goals } \\
\text { in the geography instruction, which } \\
\text { for various reasons can only be } \\
\text { achieved with difficulty in schools? }\end{array}$ \\
\hline $\begin{array}{l}\text { What criteria do you consider } \\
\text { as important for assessing the } \\
\text { difficulty of a geographical text? }\end{array}$ & $\begin{array}{l}\text { What do you see as the specificity } \\
\text { of the geographical way of } \\
\text { thinking when looking at specific } \\
\text { phenomena, problems on } \\
\text { Earth (please specific students } \\
\text { activities)? }\end{array}$ \\
\hline $\begin{array}{l}\text { What influences your approach } \\
\text { to choosing a text and } \\
\text { evaluating its difficulty? }\end{array}$ & $\begin{array}{l}\text { Does reading have the learning } \\
\text { potential to pursue geographical } \\
\text { goals? If so, try to specify it. }\end{array}$ \\
\hline $\begin{array}{l}\text { Does the development of } \\
\text { reading literacy at your school } \\
\text { be supported? }\end{array}$ & \\
\hline
\end{tabular}

Source: own research investigation 
The intent of the third phase, selective coding, was to focus the findings into a purposeful and explanatory whole that would enable us to answer the research questions. This phase involved the creation of a typology of teacher approaches to reading in the disciplines and identifying factors impacting the inclusion of reading into geography instruction.

\section{Research results}

We structure the research results into two parts, which correspond with the secondary research questions. They are interconnected because they arise out of the selective coding of respondent answers and are supported in the paradigm model (Figure 1).

What types of approaches to disciplinary reading are obvious to geography teachers?

Already during open coding, it gradually became clear that the individual statements of teachers have similar features and it would therefore be possible to distinguish several types. There was a fundamental step in the choice of such aspects that would allow the creation of a typology with a robust construction (Šed'ová, Švaříček 2013). The typology we have
Tab. 3 Typology of teacher approaches to reading in the disciplines.

\begin{tabular}{|c|c|c|}
\hline \multirow[b]{2}{*}{$\begin{array}{l}\text { Type of reading } \\
\text { in geography } \\
\text { instruction }\end{array}$} & \multicolumn{2}{|c|}{$\begin{array}{l}\text { Student activity (scale of thinking skills } \\
+ \text { frequency of participation in the learning } \\
\text { process) }\end{array}$} \\
\hline & $\begin{array}{l}\text { Emphasis on simple } \\
\text { thinking skills } \\
\text { Less active and } \\
\text { occasional inclusion } \\
\text { of students in the } \\
\text { learning process }\end{array}$ & $\begin{array}{l}\text { Use of more complex } \\
\text { thinking skills } \\
\text { Active and frequent } \\
\text { inclusion of students } \\
\text { in the learning } \\
\text { process }\end{array}$ \\
\hline $\begin{array}{l}\text { Reading to add } \\
\text { variety to geography } \\
\text { instruction }\end{array}$ & Type Emerging & Type Bridging \\
\hline $\begin{array}{l}\text { Reading as a natural } \\
\text { and functional } \\
\text { part of geography } \\
\text { instruction }\end{array}$ & $\begin{array}{l}\text { Type Partly } \\
\text { developing }\end{array}$ & Type Fluent \\
\hline
\end{tabular}

Source: authors

created utilizes two criteria identified during the axial and selective coding phases. The first point of classification is student activity - based on cognitive difficulty and/or the frequency of student participation in the learning process - as declared by teachers. The second axis of classification is the way a teacher

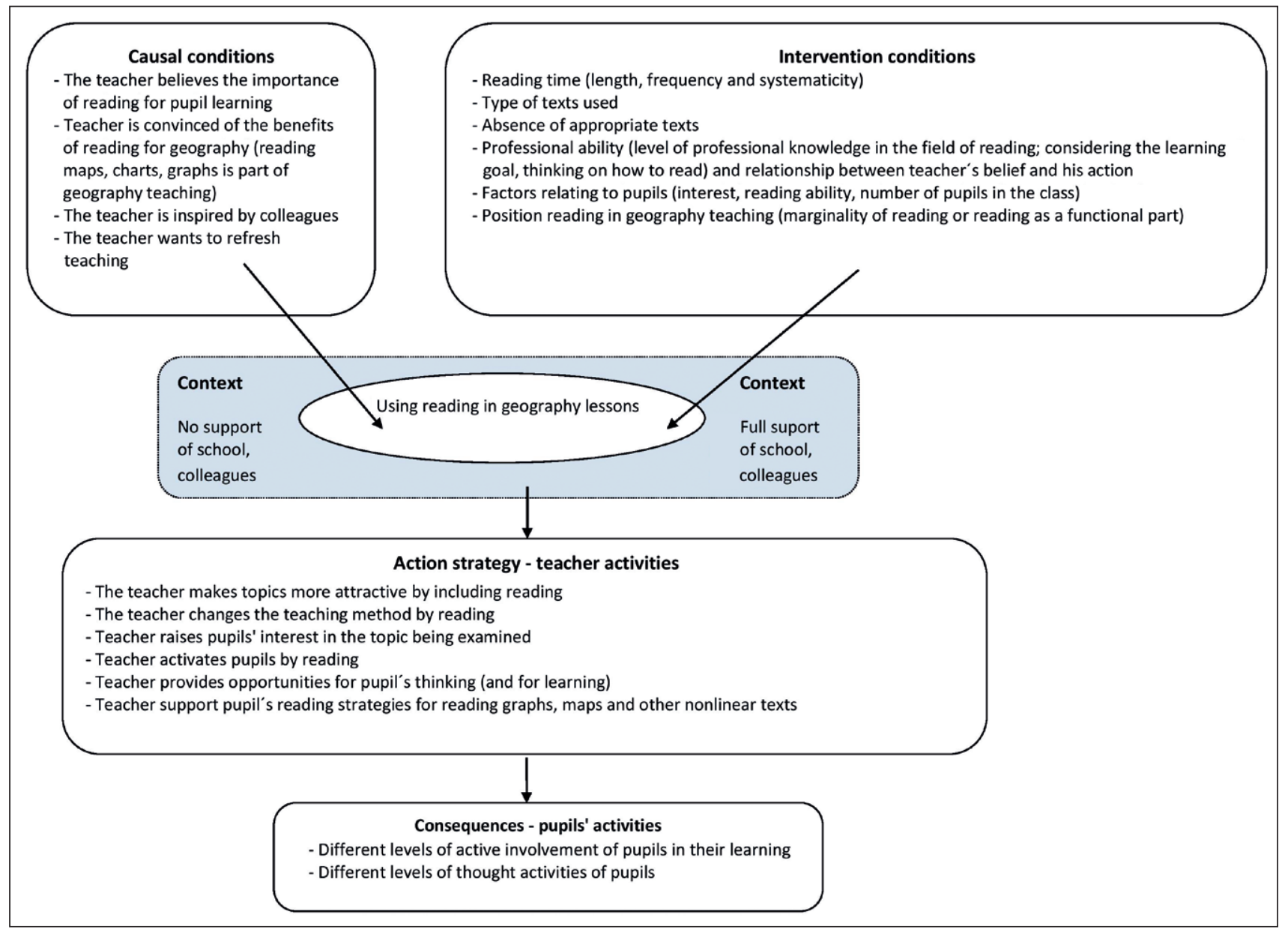

Fig. 1 Paradigm model "The inclusion of reading in geography instruction".

Source: authors 
connects reading with the attainment of geographic objectives. Whether reading is more of a coincidental element of instruction that a teacher includes to add variety, or reading is included more frequently and serves as a means of encouraging student thinking, or a teacher connects geographic and reading objectives.

The two classifying points mentioned divided respondents into four types (see Table 3).

\subsection{Type Emerging}

Emerging type teachers view reading as a means to liven up geography instruction, either by its content or by simply replacing a standard teacher lecture with a different source of information - geography textbook, travelogue or magazine article.

This is the case, for example, of Teacher V, who states:

I use geographic magazines to enliven instruction. I select articles that will capture students' interest and increase their knowledge. Primarily, these are articles concerning the life of inhabitants of a given country or natural or cultural points of interest.

Reading represents a way to add variety to instruction or an occasional method that does not engage students in the learning process. The educational potential of texts is not fully realized. Students read them primarily in order to seek new information. Teachers of this type tend to be unsure of the benefits reading has for student learning or their beliefs are not in line with their actions. In this regard, they mention the limiting influence of a various external factors, for example, the number of students in a class, disinterest of students, lack of texts. Some teachers speak of the importance of supporting the development of student literacy, but in subsequent statements they either fail to support it more or rebut it altogether.

An example is Teacher P's opinion:

I think that reading texts is a fundamental part of instruction in any discipline. ... The reality of geography instruction and the utilization of opportunities to read texts from the discipline is rather marginal. Particularly, due to the wide variety of curriculum and the time available for this discipline. It could be used as a form of home preparation (homework - read the text and based on the items learned fill in a crossword puzzle or some sort of diagram (outline or blank map).

\subsection{Type Bridging}

It is characteristic Bridging type teachers that they include reading in instruction somewhat irregularly combined with a certain, specific objective. This could be an emphasis on reading non-linear texts, such as various tables, graphs or maps.
Teacher K, for example, states:

I am not sure of anything that is 'specific' to reading in geography. With the exception of reading maps - in other disciplines this skill is rarely used; perhaps, graphs and tables - they are used in a minority of subjects. I consider reading maps, not only general geographic maps, but particularly themed maps, to be the most important addition to literacy.

Another purpose that these teachers pursue through reading is support for student thinking or certain communication skills.

An example is the approach of Teacher M, who uses reading of texts from the Internet to train students' systematic thinking:

Hypertext by its very nature is not conceived linearly. It does not dictate a hierarchical structure. That structure is constructed by the reader. In other words, it is the same as if a reader opened a book to a random page, read it and then randomly continued to another, and so on and so on, and yet it would make sense from the reader's point of view. This brilliant thought does not work, of course, unless the reader is familiar with the principle of hierarchy; the result is a chaotic succession of pages with no rhyme or reason that is everything but not something meaningful. In short, new sources of information lack what books have, a sense of succession and order, provided by someone who is headed somewhere and who knows where he is headed.

Student activities working with texts are not often included, but they involve higher level thinking and students are, therefore, able to actively participate in the teaching process. Teachers of this type are the least represented in the research sample.

\subsection{Type Partly developing}

Teachers of this type generally believe in reading's importance in teaching students and view reading as a tool that enables students to think and participate in their own learning.

For example, according to Teacher L:

Students are improving in working with text. While working with text, students are actively engaged in the learning process. In other words, 'Every thought spoken by the teacher is a shame.'

Partly developing type teachers include reading in instruction fairly frequently, though it is not clearly systematic and goal oriented.

Intellectually more challenging student activities are included rather intuitively. However, teacher responses show a level of uncertainty about how to implement reading in the disciplines. E.g. teachers use modal verbs: "Texts can be good to tune in to the 
topic, they can help to get students' attention, their interest", teacher N. This is likely influenced by the fact that, unlike their counterparts abroad, they are not equipped with know-how regarding possibilities for reading in the disciplines (how to read with students, how to select and assess texts, etc.). This type of teacher approach is the most common in the research sample.

\subsection{Type Fluent}

This type of teacher sees reading as an integral part of geography instruction. Their beliefs is founded both on the indispensability of reading for active student learning as well as reading's contribution to the achievement of a broader spectrum of geographic objectives $^{1}$. In contrast to the preceding type, Type Fluent seeks to add a systematic and more comprehensive approach to the inclusion of reading. This is manifest, first, in teacher efforts to develop literacy skills that aid in the comprehension and in further work with texts.

Teacher A, for example, defends her approach:

Students learn to think in broader contexts, to view issues critically, to not fear speaking up, or to change their opinions after gaining new information ... to this point, I think, only 'working with texts,' as yet, I have not focused intentionally on the development of reading strategies. I am learning to work with that.

Second, it is manifest by teachers thinking about how to connect the objectives of geography instruction with the potential of a text and the needs of their students.

Teacher 0, for example, states:

I cannot imagine that anyone would not read in geography. I do not focus reading on textbooks, I use a variety of texts from magazines or from the web. I must find out how difficult the text is. Will students understand it? Does it contain many foreign words? How long are the sentences? Is it complicated? I try to read, at least a bit - at least a paragraph, in every class. Read in a variety of ways. Don't let it be a simple read through a textbook. I must know why I am inserting it, why a child should read in this class. What objectives am I following? Two objectives - literacy - I lead them to read also by the things that I present to them.

This teacher approach is reflected in student activities that require higher thinking skills and, therefore,

1 We cannot claim that other types of teachers did not recognize a connection between reading and geography instruction, but this connection differs. It is either not consciously considered or it fits within a narrow spectrum of geographic objectives - for example, reading to attain some isolated information. their own active involvement in learning. Teachers also emphasize students learning one other.

E.g. Teacher J:

On a simple level - searching for and sorting information. More difficult level - the ability to perceive that the text is always written from some point of view. It is the basis for further discussion and the ability to defend one's opinion.

Type D teachers tend to see themselves as readers and/or teachers that are responsible for the development of student reading.

No distinct boundaries separate the types of approaches. This is due to the complexity of research topic and the fact that teachers can shift among the various types of approaches as they develop professionally.

What causes the apparent similarities or differences among teacher approaches?

The typology of teacher approaches to reading in the disciplines described above is based on a combination of two points of classification or factors that influence teachers' approaches to reading in the disciplines. However, the reality is more complicated - the teacher's approach is shaped by a number of other factors. Moreover, even within one type, teachers do not show completely identical features. A deeper understanding is significantly aided by the paradigmatic model (Figure 1). It captures the factors identified by the research, which are part of the causal, intervening conditions and the wider context. These factors are interconnected and operate directly or indirectly in various phases of the implementation of reading in the disciplines. The specific form of the defining factors is dependent on the teacher's approach and his or her subsequent actions which impact student activities. As such it is important to also consider what led and leads teachers to include reading, what type of environment they work in and any other factors that may impact their work.

The research demonstrates the variety of reasons, i.e. causal conditions, that motivate teachers to include reading. Most frequently, teachers spoke of the importance of reading for teaching students at the general level. For example, Teacher $\mathrm{CH}$ observed, that:

In my opinion students much more easily remember learning material that they have studied themselves and discussed among themselves.

Some teachers noted the importance of teaching with geographic objectives. Responses also frequently indicated that reading is a means for enlivening geography instruction. Responses of teachers indicates that the way to more thoroughly integrate reading can truly begin with the "mere" enlivening of instruction.

Specifically, Teacher A states: 
The very first motivator was to make instruction more captivating, to make classes more entertaining - for students and certainly for me, as well. I tried to both topics that came up in the textbook - monsoons - along with topics that were only marginally related to the class's content and which may correspond with a current event.

Some teachers consider changes in topic to be enlivening to instruction (focus on interesting, or current-event topics or traditional topics viewed differently). Others see reading as another form of instruction, enabling students to engage in the learning process more thoroughly. For example, Teacher $\mathrm{N}$ thinks that: "a well selected text can surprise, frequently raising additional questions and at times even emotional responses." A fourth reason that expressed itself rather infrequently in teacher responses was inspiration from colleagues or schoolwide focus.

Teacher $\mathrm{N}$ mentions this reason:

In part, I was influenced by cooperation with a colleague in paired instruction. This colleague frequently works with texts and she persuaded me in this direction upon my return from maternity leave.

In reality as teacher responses demonstrate (see teacher $\mathrm{N}$ ), it is a combination of various causal factors that encourages teachers to include reading in instruction. The combination of an attempt to enliven instruction and to tap into the benefits of reading for student learning was common. Some teachers perceive benefits of reading in students' active participation in the learning process, as they ponder over texts. On the other hand, however, teacher responses make it clear that they include reading rather infrequently to add variety to instruction.

As soon as a teacher includes reading in a geography instruction, a number of factors arise and influence its implementation. One significant factor is the context, i.e. the specific situation at a given school that either does or does not support reading across all subjects. This lies in the presence (or absence) of literacy within a school's educational plan, in opportunities for cooperation and additional teacher training in reading in the disciplines, etc. No less important is the school's culture, which Hattie (2012) considers an integral part of any long-term improvement of learning teachers and students. Intervening conditions include factors that can either help or hinder the inclusion of reading in instruction. Table 4 presents all factors, including a description of these two sides, though we do find smooth transitions between them. Whether the character of a given factor proved to be supporting or limiting arises out of the research's theoretical framework with additional support from the data gathered. The ultimate character of a factor was often determined by recognizing clues in the teacher responses.

For example, Teacher P writes:
It is difficult to retain students' attention during class and reading is often done automatically, without thinking. Sometimes they do not even know what they read about. For this reason, the texts should not be very long, enough to read in 10 or 15 minutes.

From this teacher's claim, we can deduce that student lack of attention is perceived as a threat that could limit the inclusion of reading in instruction. We can also determine that the teacher lacks understanding and know-how, concerning reading in the disciplines. Specifically, the teacher does not appear to bring any structure to reading assignments, he does not work with literacy objectives (this becomes clear from the statement "what they read about"), and reading is given relatively little time, limiting the opportunity for students think more deeply.

Based on the data, it was not possible to clearly determine whether the factor summarily labelled as "type of texts utilized" has a supporting or limiting nature. From teacher responses, we can only deduce that teachers supporting reading utilize texts that encourage student thinking (e.g. by containing various points of view regarding a given issue). The fact that many teachers mention a lack of appropriate texts or difficulty finding and obtaining such texts should not be overlooked.

\section{Discussion and conclusions}

The research revealed that between the approaches of geography teachers to the inclusion of reading, there are certain identical, resp. different features, which allowed the creation of a typology. The types were distinguished on the basis of two classification aspects and were called Emerging, Bridging, Partly developing and Fluent. The boundaries between the individual types are not sharp, teachers can switch between types during their professional learning and the approach of the included teachers is not completely identical within any type. This is due to the complexity of the phenomenon, which largely captures the Paradigmatic model developed by the authors (Figure 1). The paradigmatic model is also a tool that significantly helps to individualize each case. The typology of approaches will indicate what type of approach corresponds to a particular teacher, but examining the relationships and forms of individual conditions (context), strategies of action, and consequences will allow the teacher's approach to be better understood. In our proposed typology, the so-called zero type is missing. That is, a type of teacher who would not include reading in teaching at all. With regard to the situation in contemporary Czech education, however, we do not anticipate this situation, because textbooks and atlases are part of school's lessons and a certain reading of texts, including maps therefore takes place at least sometimes. 
Tab. 4 Factors influencing teachers in including reading in geography instruction.

\begin{tabular}{|c|c|c|}
\hline Factor & Supporting in nature & Limiting in nature \\
\hline $\begin{array}{l}\text { Position of school leadership } \\
\text { and colleagues regarding student } \\
\text { literacy development }\end{array}$ & $\begin{array}{l}\text { Support from school leadership and colleagues. } \\
\text { Teachers develop cooperation and take inspiration } \\
\text { from one another. }\end{array}$ & $\begin{array}{l}\text { Negative or neutral position from school leadership } \\
\text { and colleagues. Teachers do not work together. }\end{array}$ \\
\hline $\begin{array}{l}\text { Teacher beliefs concerning } \\
\text { the importance of reading }\end{array}$ & $\begin{array}{l}\text { Teacher believes in the benefits of reading - } \\
\text { for developing thinking and learning and } \\
\text { for learning geography. }\end{array}$ & $\begin{array}{l}\text { Teacher is skeptical of the benefits of reading, } \\
\text { reading is more of a marginal activity, separated } \\
\text { from other activities in geography instruction. }\end{array}$ \\
\hline $\begin{array}{l}\text { Teacher's professional } \\
\text { preparedness }\end{array}$ & $\begin{array}{l}\text { Teacher knows the scale of literacy skills, works } \\
\text { with objectives, provides feedback, continually } \\
\text { develops his or her professional knowledge and } \\
\text { vision, utilizes assessments of student performance. }\end{array}$ & $\begin{array}{l}\text { Teacher is not familiar with the possibilities of } \\
\text { utilizing literacy skills, does not work with objectives, } \\
\text { does not provide feedback, does not develop skills } \\
\text { for including texts in instruction. }\end{array}$ \\
\hline $\begin{array}{l}\text { Role of reading in attaining } \\
\text { geographic objectives }\end{array}$ & $\begin{array}{l}\text { Reading is a tool of geography instruction and/or } \\
\text { one of the objectives of geography education. }\end{array}$ & $\begin{array}{l}\text { Reading is an accessory tool of geography } \\
\text { instruction, operating simply as a means of } \\
\text { enlivening instruction. }\end{array}$ \\
\hline $\begin{array}{l}\text { Relationship between beliefs } \\
\text { and action }\end{array}$ & $\begin{array}{l}\text { Teacher has a clear understanding of the benefits } \\
\text { of reading and employs strategies to effectively } \\
\text { include reading in instruction. }\end{array}$ & $\begin{array}{l}\text { Teacher is unsure, grasps certain aspects of reading's } \\
\text { importance, but the connection between beliefs } \\
\text { and action is contradictory. }\end{array}$ \\
\hline $\begin{array}{l}\text { Student factors (interest } \\
\text { /disinterest; attention; class size; } \\
\text { level of literacy skills; etc.) }\end{array}$ & $\begin{array}{l}\text { Viewed as circumstances that should be anticipated } \\
\text { and around which instruction should be planned. }\end{array}$ & Viewed as limits or threats. \\
\hline Lack of texts & $\begin{array}{l}\text { Teacher actively searches for texts, thinks about } \\
\text { what types of texts and why he/she is searching. }\end{array}$ & $\begin{array}{l}\text { Teacher is skeptical, does not have clear } \\
\text { objectives for working with texts and, as a result, } \\
\text { does not know what texts to seek. }\end{array}$ \\
\hline Time for reading & $\begin{array}{l}\text { Reading is included regularly and often. Time is set } \\
\text { apart for individual reading and reading assignments } \\
\text { are broad enough to allow students to ponder. }\end{array}$ & $\begin{array}{l}\text { Reading is including infrequently and at random. } \\
\text { Reading and reading assignments are given } \\
\text { a limited amount of time, which hardly allows } \\
\text { students to think on the readings. }\end{array}$ \\
\hline
\end{tabular}

* The order in which the factors are presented does not reflect their significance regarding reading in the disciplines.

Source: authors

Teachers do not seem to integrate reading with the primary goal of developing reading strategies (as mentioned content area reading). Similarly, it is not possible to document the approach of teachers that would correspond to the disciplinary literacy. Rather, the assembled data show that geography teachers incorporate reading more or less intuitively and that teacher's approach to reading in the disciplines seems to reflect preferences of their general concept of teaching, which have a variety of impacts on the teaching of students. If a teacher prefers instruction that is rather "encyclopedic" in nature, during which students are less active and tend to be mere passive receivers of prepared facts or interesting information, then reading will likely be less interesting to the teacher. Any potential student reading leads to the mere searching for facts. In an opposite case, when a teacher prefers student activities that require greater participation in the process of learning geography and by studying geography and additional cross-disciplinary skills (e.g. cooperation), this focus becomes evident in the manner of reading and utilizing texts. Of course, a number of variations exist between these two distinctive types. Research also suggests that reading could be a tool to allow teachers to change their teaching. This is indicated by the statements of teachers type Emerging, who state the reason for including reading as "activating students", and the statements of teachers type Partly developing, who already talk about active learning of students and distinguish them from another form, although not directly talking about it. A similar conclusion can be found in the research of Hanus and Havelková (2018) in connection with the preferred mapping skills. Furthermore, it would be possible to examine whether and under what condition the implementation of reading can contribute to the sharing of the teacher's concept of teaching. Considering the impacts of learning on students, Pearson et al. (2010) consider a teacher's approach that enables students to carry out real, practical activities ("hands on") and use reading and writing as necessary tools to unlock additional specifics of the discipline to be most beneficial. The cited authors base their opinions on a number of projects (e.g. Science IDEAS, Guided Inquiry supporting Multiple Literacies), which share a common emphasis on the connection of inquiry-based science and the inclusion of reading and writing. This does not mean that learning facts is not necessary, but it is not effective to continue to do only that. This approach most nearly approximates type Fluent as defined in our research.

A teacher's approach is not formed on its own but is influenced by mutually connected factors that 
impact the implementation of reading in the disciplines at differing degrees and in different times. In the paradigm model (Figure 1), these factors take the form of causal or intervening conditions or the context, in which a teacher works. Rather than present a list of supporting or limiting factors, the research proposes that the factors be viewed as being either supporting or limiting in nature (Table 4). Lazarová et al. (2012) view factors in a similar way, though in connection with organizational teaching. They point out that it depends on the specific situation. It is even possible that a factor could be considered an obstacle to teaching by one teacher and yet serve as a stimulus for positive change for another. For example, student disinterest can lead either to the reluctant inclusion of reading, with a noticeable lack of student participation, or to the searching out of texts and teaching methods that would increase student interest. The factors probably affect all teachers, but their specific form differs, and it is partly possible to say that teachers of, for example, type Emerging are united by a certain form of a specific factor. These teachers typically report that reading takes up little space in lesson. Type Fluent teachers often include reading and working with text is a key activity for students during the lesson. Research does not allow this statement to be transferred to the whole set of factors and all types of approaches. Further research could focus on examining the factors that influence the implementation of reading. This should contribute to the knowledge of the teacher's needs and thus more effectively support his professional learning.

Part of any teacher's professional knowing is a set of beliefs that significantly impact the teacher's approach. It appears that teachers corresponding with Type Fluent have formulated a specific and for learning students - a beneficial understanding of the significance of reading and data show that they are fulfilling it. Responses from other teachers, particularly Type Emerging, in contrast, demonstrate uncertain beliefs regarding the significance of reading in geography instruction. This is manifest in their failure to provide more specific examples of generally formulated benefits of reading or, in some cases, by contradicting those stated benefits in other parts of their responses. This is not simply about gaining more knowledge of various strategies or techniques. Rather, it involves altering beliefs, which would then lead to change in existing personal theories.

The implemented research is accompanied by certain limits. One of them is the method of data collection - a written questionnaire with open-ended questions. There are several risks to this approach. It is possible that teachers may feel the need to respond as expected. If the teacher perceives the current emphasis on the development of reading in the Czechia, then he may think that it is "appropriate" to join in this direction, although the teacher himself does not share this opinion. Abroad, similar conclusions are reached by Milner et al. (2012), whose results suggest that teachers' own beliefs may be delayed (in the event of a change in the way disciplines are taught). Their final action are more influenced by the expected opinion than by their own. It is possible that some of the teachers involved in our research may have had this feeling as well. This would be indicated, for example, by uncertain wording about the benefits of reading. A way of talking in which teachers feel safe and feel that there are no "right" answers could help. The second pitfall is the inconsistent definition (understanding) of certain term. A typical example is the word "text". It is possible that teachers imagine only continuous texts, for example, as text. The choice of a written inquiry is also debatable. This is because two teachers from the sample we addressed answered so briefly and in general that it was not possible to responsibly interpret their answers and include them in the research. Nevertheless, this experience is also important, as it can indicate the uncertainty of teachers and their educational needs. The third limit concerns the choice of research tool, specifically the method of grounded theory. Although coding was done by two authors, it must be added that the resulting typology, including the compiled paradigmatic model, is probabilistic. It would be possible to explore the approach to reading in the discipline for a wider range of teachers - without our chosen deliberate choice (reading experience). This research could examine and complement the existing typology in order to contribute to further professional learning of teachers.

Greater knowledge of teacher approaches to reading in the disciplines, including factors that influence it, is important for teacher training in this area. Without including a teacher's earlier knowledge, skills and beliefs, the effectiveness of his or her professional training is threatened (Bransford et al. 2000; Timperley 2011; Korthagen 2017). Otherwise, teachers may reject or only acquire superficial understanding of new approaches and practices, resulting in a limiting effect on the progression of students through their teaching (Timperley et al. 2007). A deeper misunderstanding of a given method, that teachers are introducing, can lead to a situation that Timperley (2011) calls "over-assimilation". This means that a teacher implements the method (e.g. reading) without knowing what makes it important or what benefits it brings to learning students. The teacher thinks that what he or she is doing works well and is in line with the newly introduced method. However, the difference between what is being proposed and what is actually being taught can, in reality, be quite large. This can be seen in our findings (consider the discussed contradiction between a teacher's declared beliefs concerning the benefits of reading for active student learning and his/her approach or actions in instruction - the teacher P).

The effective implementation of reading in the disciplines in geography instruction requires us to 
know and understand additional realities. Additional research should focus on students and their teachers, the educational potential of various source materials for reading and the (non-)functional connection between reading in the disciplines and geography instruction, comparison of reading across subjects, etc.

This article was supported by the research project of the Grant Agency of the Charles University: PROGRES Q17 "Teacher Preparation and the Teaching Profession in the Context of Science and Research".

\section{References}

Bransford, J., Brown, A., Cocking, R. (2000): How People learn: Brain, Mind, Experience and School. Washington: National Academy Press.

Buehl, D. (2011): Developing readers in the academic disciplines. Newark: International Reading Association.

Catling, S. (2004): An understanding of geography: The perspectives of English primary trainee teachers. GeoJournal 60(2), 149-158, https://doi.org/10.1023 /B:GEJ0.0000033575.54510.c6.

Common Core State Standards (2010): http://www .corestandards.org/wp-content/uploads/ELA Standards1.pdf.

Common Core English Language Arts and Geography Connections (2013): http://www.nationalgeographic .org/media/common-core-ela-geography-connections.

Gilles, C., Wang, Y., Smith, J., Johnson, D. (2013): “I'm No Longer Just Teaching History" Professional Development for Teaching Common Core State Standards for Literacy in Social Studies. Middle School Journal 3(44), 34-43, https://doi.org/10.1080/00940771.2013.11461853.

Griffith, R., Lacina, J. (2017): Teacher as Decision Maker: A Framework to Guide Teaching Decision in Reading. The Reading Teacher 7(4), 501-507, https://doi.org /10.1002/trtr.1662.

Hanus, M., Havelková, L. (2018): Teacher's Concepts of MapSkill Development. Journal of Geography 118(3), 1-16, https://doi.org/10.1080/00221341.2018.1528294.

Hattie, J. (2012): Visible Learning for Teacher. Maximalizing Impact on Learning. London and New York: Routledge, https://doi.org/10.4324/9780203181522.

Havlínová, H. (2016): Proměny pohledu na výuku čtení v české škole prizmatem výzkumů: od nácviku techniky čtení k rozvoji čtenářské gramotnosti. Orbis Scholae 10(2), 145-157, https://doi.org/10.14712 /23303177.2017.7.

Hendl, J. (2005): Kvalitativní výzkum: základní metody a aplikace. Praha: Portál.

Hutner, T. L., Markman, A. B. (2016): Proposing an Operational Definition of Science Teacher Belief. Journal of Science Teacher Education 2(6), 675-691, https:// doi.org/10.1007/s10972-016-9480-5.

Janík, T. (2005): Znalost a další pedeutologické kategorie. In: Janík, T.: Znalost jako klíčová kategorie učitelského vzdělávání. Brno: Paido, 32-33.

Korthagen, F. (2011): Jak spojit praxi s teorií: Didaktika realistického vzdělávání učitelů. Brno: Paido.

Korthagen, F. (2017): Inconvenient truth about teacher learning: toward professional development 3.0. Teachers and Teaching: Theory and Practice 23(4), 387-405, https://doi.org/10.1080/13540602.2016.1211523.

Koubek, P. (2015): Subjektivní teorie řídící jednání učitelů v kontextu jejich profesního rozvoje: teoretická a empirická východiska výzkumu. In: Švec, V. et al.: Znalostní báze učitelství. Brno: Masarykova univerzita, 13-32, https://doi.org/10.5817/CZ.MUNI.M210-7961 $-2015$.

Lazarová, B., Pol, M., Hloušková, L., Novotný, P., Sedláček, M. (2012): Organizační učení v odborných diskursech. Pedagogická orientace 22(2), 145-161, https://dx.doi .org/10.5817/PedOr2012-2-145.

Minaříková, E., Janík, T. (2012): Profesní vidění učitelů: od hledání pojmu k možnostem jeho uchopení. Pedagogická orientace 22(2), 181-204, https://dx.doi.org/10.5817 /PedOr2012-2-181.

Moje, E. B. (2008): Foregrounding the Disciplines in Secondary Literacy Teaching and Learning: A Call for Change. Journal of Adolescent and Adult Literacy 52(2), 96-107, https://doi.org/10.1598/jaal.52.2.1.

Next Generation Science Standards (2013): www .nextgenscience.org/search-standards.

Pearson, P. D., Moje, E., Greenleaf, C. (2010): Literacy and Science: Each in the Service of the Other. Science 23(328), 459-463, https://doi.org/10.1126/science .1182595 .

Radváková, V. (2015): Práce s textem na střední škole. Orbis Scholae 9(3), 87-109, https://doi.org/10.14712 /23363177.2013.6.

Shanahan, T., Shanahan, C. (2008): Teaching Disciplinary Literacy to Adolescent: Rethinking Content-area Literacy. Harvard Educational Review 7(1), 40-59, https://dx.doi .org/10.17763/haer.78.1.v62444321p602101.

Shanahan, T., Shanahan, C. (2012): What Is Disciplinary Literacy and Why Does It Matter? Top Lang Disorders 3(1), 7-18, https://doi.org/10.1097/TLD .0b013e318244557a.

Shanahan, C. (2013): What Does It Take? The Challenge of Disciplinary Literacy. Journal of Adolescent and Adult Literacy 57(2), 93-98, https://doi.org/10.1002/jaal .226 .

Slavík, J., Janík, T., Jarníková, J., Tupý, J. (2014): Zkoumání a rozvíjení kvality výuky v oborových didaktikách: metodika 3A mezi teorií a praxí. Pedagogická orientace 24(5), 721-752, https://dx.doi.org/10.5817/PedOr 2014-5-721.

Strauss, A., Corbinová, J. (1999): Základy kvalitativního výzkumu: postupy a techniky zakotvené teorie. Brno: Sdružení Podané ruce.

Šed'ová, K., Švaříček, R. (2013): Jak psát kvalitativně orientované výzkumné studie. Kvalita v kvalitativním výzkumu. Pedagogická orientace 23(4), 478-510, https://doi.org/10.5817/PedOr2013-4-478.

Švaříček, R., Šed’ová, K. et al. (2007): Kvalitativní výzkum v pedagogických vědách. Praha: Portál.

The New Zealand Curriculum (2009): http:// nzcurriculum .tki.org.nz/The-New_Zealand-Curriculum.

Timperley, H., Wilson, A., Barrar, H., Fung, I. (2007): Teacher professional learning and development. Best evidence synthesis iterativ. Ministry of Education, New Zealand, www.minedu.govt.nz.

Timperley, H. (2011): Realizing the Power of Professional Learning. McGraw-Hill Education, https://dx.doi.org $/ 10.1111$. 